Karolina Wierczyńska*

wierka2000@wp.pl

Institute of Law Studies

Polish Academy of Sciences

ul. Nowy Świat 72

00-330 Warsaw, Poland

\title{
The Polish-German Cultural Heritage Relationship in 1990-2019 - Main Controversies and Areas of Progress ${ }^{* *}$
}

\begin{abstract}
This contribution refers comprehensively to the issues surrounding the legal and practical aspects of the Polish-German relationship in the area of cultural heritage between 1990-2019, taking into account the Second World War trauma which still shapes such mutual relations. The main research problems focused on the contexts of Poland's and Germany's policies towards the problems related to cultural heritage. Interestingly, mutual cooperation in many instances takes place regardless of the official political line of a given State and engages non-state institutional subjects on many levels. The point is that Polish-German relations in the area of cultural heritage proceed regardless of the Polish and German official political narratives and claims in the context of the cultural
\end{abstract}

\footnotetext{
* Karolina Wierczyńska is Associate Professor at the Institute of Law Studies of the Polish Academy of Sciences in Warsaw (Poland) and managing editor of "Polish Yearbook of International Law". Her research interests focus on international criminal law and jurisprudence. In her two monographs (published in Polish in 2010 and 2016) she explored the notion of genocide in the context of the jurisdiction of international criminal ad hoc tribunals and admissibility before the ICC. She recently co-edited two volumes: Fragmentation vs. the Constitutionalisation of International Law: A Practical Inquiry, London - New York 2016, and The Case of Crimea's Annexation under International Law, Warsaw 2017.

** The author wishes to acknowledge that some of the research for this article was carried out and co-funded by the European Union within the project HEURIGHT: The Right to Cultural Heritage - Its Protection and Enforcement through Cooperation in the European Union, ERA-NET, JPI Heritage Plus "Cultural Heritage and Global Change".
} 


\section{VARIA}

Karolina Wierczyńska

heritage lost and/or not returned during and after the Second World War. Paradoxically, the wider perspective shows that Polish-German relationships in the area of cultural heritage refer currently not only to lost goods but to broader cooperation in many aspects of cultural heritage, such as the preservation of cultural goods, regional cooperation, etc., which is conducted and developed by non-governmental organizations, societies, and foundations (including ordinary people). They seem to have a leading role in the reconciliation processes of the two States.

Keywords: cultural heritage, Poland, Germany, reconciliation, restitution

\section{Introduction}

The Polish-German relationship has always been both intense and complicated. The main dividing lines in the current relations between the two States refer to a range of problems stemming from the Second World War (WWII). Even though the war has been over for more than seven decades, it impacts the relationship between the two States, including in the realm of cultural heritage. The present contribution is based on a previous study by the present author titled: Legal Aspects of Polish-German Relationships in the Area of Cultural Heritage in 1990-2017. ${ }^{1}$ This study basically took into account the broad scope of bilateral cooperation in the area of cultural heritage as widely understood, including the international legal background, "heritage lost/not returned", and other areas of cultural cooperation in order to focus on the legal problems which constitute the main controversies referring to the cooperation between both States. On the other hand, the study also described the strong sides in the countries' common relations, which mostly referred to then-current cooperation. This article, extensively based on the results of that study, goes beyond 2017 and includes an exploration of the current political narratives. It poses the two-pronged question: To what extent is the mutual cooperation in the area of cultural heritage dependent on the States themselves and public dialogue, and is it possible to overcome the negative traumatic past which is of ten exploited for pragmatic political goals? ${ }^{2} \mathrm{~A}$ positive answer

\footnotetext{
1 Available online at: http://heuright.eu/wp-content/uploads/2018/07/karolina_wierczynska_PolandGermany-studium2017_heuright.pdf [accessed: 15.03.2019]. The current contribution is aimed at developing the results obtained in that study.

2 See J. Barcz, J. Kranz, Reparacje od Niemiec po drugiej wojnie światowej w świetle prawa międzynarodowego. Aspekty prawa i praktyki [Reparations from Germany after the Second World War in the light of international law: practical and legal aspects], Dom Wydawniczy Elipsa, Warszawa 2019, pp. 339-367.
} 
to this question has its rationale in the observation made by many scholars that the current Polish-German relations are - in the area of cultural heritage - a dynamically developing domain, despite the WWII's shadow.

At the same time the wartime trauma is still a major context of the Polish-German relationship, which for a long time has been perceived through the lens of mutually exclusive narratives of victimhood. This shapes the various current interplays: on one hand it is connected with the extermination of Polish citizens, Nazification, the Holocaust, and the fight against Polish culture and science; and on the other it concerns the problem of German inhabitants expelled from the territories annexed to Poland during the period of Polish People's Republic, and the partial destruction of their centuries-old culture in those territories.

The first part of this article takes into account the factual, historical, and legal background of the cooperation between both States beginning in 1990. Secondly it refers to the state of current common obligations. Next it refers to the unsolved questions surrounding the "heritage lost", i.e. the cultural heritage which was basically stolen from Poland during WWII and never returned, and the German cultural heritage which was not returned to the State of its origin. Subsequently, the article discusses the obstacles and/or unresolved questions and main controversies in the current mutual relations which impede smooth and unconditional cooperation in that regard. It specifically focuses on the question of Berlinka (the Prussian State Library in Berlin, Preussische Staatsbibliothek zu Berlin) ${ }^{3}$ as the negotiations concerning this controversy are ongoing. Special attention is devoted to the motivation of both States, and the issue might be considered as symbolic of the current postwar relations. However, the contribution also points out the many areas where joint cooperation is unaffected by the traumatic past and is developing smoothly. The conclusion discusses the prospects for future cooperation, offering the prospect of reconciliation despite the unresolved problems from the past.

\section{The Legal, Historical, and Factual Background}

After WWII there were many unresolved issues between Poland and Germany, starting from, inter alia, the recognition of borders, a peace settlement, and the question of restoration of property (including cultural goods). This past has had an extreme impact on the evolution of the present Polish approach towards Germans, including the present Polish-German relationship, especially because some ques-

\footnotetext{
3 Berlinka, or the Prussian State Library is the name for a collection of original German manuscripts originally kept at the Prussian State Library in Berlin. The collection, which is a part of German cultural heritage, was evacuated from Berlin to avoid bombings during WWII, and is now stored in Poland. The question of its ownership has been subject to an ongoing debate between Poland and Germany. Stiftung Preußischer Kulturbesitz, Holdings Evacuated to Poland, https://www.preussischer-kulturbesitz.de/en/priorities/provenance-research-and-issues-of-ownership/wartime-losses/holdings-evacuated-to-poland.html [accessed: 20.03.2019].
} 


\section{VARIA}

Karolina Wierczyńska

tions have never been definitely closed and have a tendency to reappear in changing political narratives, like the question of Polish expectations concerning reparations from Germany, or the ownership and place of storage of the Prussian State Library in Berlin, ${ }^{4}$ which was relocated during the war to what afterwards became Polish territory, where it is still located.

\section{Polish claims}

It seems that for Poland the most decisive factors in its approach toward Germany are/were the occupation of Polish territory by German troops and the extermination of 6 million Polish citizens; the question of territorial revisionism (present for example in Adenauer's policy) directed toward Poland; as well as the looting of Polish cultural heritage during WWII, during which - in line with Hitler's policy to establish a museum in Linz ${ }^{5}$ - German troops looted monuments, the contents of museums and libraries, and private collections. ${ }^{6}$ Today it is now almost impossible to reconstruct a complete catalogue of Polish war losses. The reasons for such a situation vary. It must be noted that in many instances this was a consequence of the lack of adequate records, for example incomplete registers being kept during the war. In addition, some registers, museum records, inventory lists, and documentary archives were intentionally destroyed or removed by both the Nazis and the Soviet Army. During the war a group of historians and librarians undertook initial attempts to register the war losses and compiled the first collective lists of missing works of art from both public and private collections. The data was submitted to the Office of Restitution of Cultural Losses of the Government of the Republic of Poland in exile and was used by its director, Karol Estreicher. Subsequently he authored a publication entitled Cultural Losses of Poland: Index of Polish Cultural Losses During the German Occupation, 1939-1944 (London 1944), ${ }^{7}$ which was the first such detailed list of losses. After the war, the Bureau for Revindication and Reparations ${ }^{8}$

4 M. Żółtowski, Zbiory Biblioteki Pruskiej w Polsce. Studium przypadku [Collection of Prussian library in Poland. Case study], Wydawnictwo Uniwersytetu Warszawskiego, Warszawa 2012.

5 K.D. Alford, Hermann Göring and the Nazi Art Collection: The Looting of Europe's Art Treasures and Their Dispersal After World War II, McFarland \& Company, Jefferson, NC 2012; A. Chechi, The Settlement of International Cultural Heritage Disputes, Oxford University Press, New York 2014, p. 262.

6 N. Cieślińska-Lobkowicz, Węzeł Poczdamski. O powojennych rewindykacjach dóbr kultury zwiazzanych ze zmiana polskich granic [Potsdam's knot. About post-war vindications of cultural goods connected with the change of borders], in: G. Czubek, P. Kosiewski (eds.), Dobra kultury i problemy własności. Doświadczenia Europy Środkowej po 1989 roku [Cultural goods and the problem of ownership. Experience of Central Europe after 1989], Fundacja im. Stefana Batorego, Warszawa 2005, p. 209.

7 The 2003 reedition available online at: http://mbc.malopolska.pl/dlibra/doccontent?id=13505 [accessed: 22.03.2019].

8 In the mentioned study another name was used, namely the "Bureau for Restitution and Compensation", but I decided to follow the nomenclature proposed by W. Kowalski, Poland. Part l: Historical Overview, "Spoils of War" 1995, Vol.1, p. 23, https://www.lootedart.com/web_images/pdf2016/Spoils\%20of\%20War\%201. pdf [accessed: 20.03.2019]. 
at the Ministry of Culture and Art used the information contained in the publication and enriched the register with additional data. However, owing to political reasons it was closed in 1951. There was no other institution at the time collecting such data.

Post-war statistics reported more than 500,000 missing cultural objects (removed and destroyed), and it must be noted that this list does not represent the full extent of the losses. After 1992, a detailed inventory of losses allowed the then Ministry of Culture and Art to put into the internet database information on over 60,000 missing objects, out of which photographic documentation was included for only 10,000 of the registered items (which included, inter alia, 13,000 pictures, about 8,700 engravings and drawings, over 4,000 gold objects, 3,500 sculptures, and 4,500 pieces of furniture and other wooden products). ${ }^{9}$

\section{German claims}

For Germany the end of war was connected with the loss of a former part of its territory (including loss of property and cultural heritage) and the complicated status of the German minority in Poland, as well as forced resettlements/expulsions of German nationals from the territory of Poland after the war (Zwangsumsiedlung), which cannot be treated in isolation from other acts of murder, rape, and physical exploitation. ${ }^{10}$ The Federal Republic of Germany paid very limited individual

\footnotetext{
9 See the data from the Polish Ministry of Foreign Affairs: http://www.msz.gov.pl/en/foreign_policy/ restitution_of_works_of_art/war_losses. The lists of war losses and publications including war losses are available here: http://lootedart.gov.pl/en/The-Division-for-Looted-Art. On appraisal, estimation, and registration of Polish losses, see W. Kowalski, An Appraisal of the Losses to Polish Cultural Heritage Resulting from German Aggression During the Second World War, in: W. Góralski (ed.), Polish-German Relations and the Effects of the Second World War, Polish Institute of International Affairs, Warsaw 2006, pp. 45-67 and idem, Restytucja dóbr kultury utraconych przez Polskę w okresie II wojny światowej jako element polskiej polityki zagranicznej realizowanej przez Ministerstwo Spraw Zagranicznych RP w latach 1999-2009 [Restitution of cultural goods lost by Poland during World War II as an element of Polish foreign policy implemented by the Ministry of Foreign Affairs of the Republic of Poland in 1999-2009], in: W. Kowalski, M. Kuhnke (eds.), Looted and Recovered. Restitution by the Ministry of Foreign Affairs of Poland's Cultural Property Lost During World War II, Ministerstwo Spraw Zagranicznych, Warsaw 2011, p. 9.
}

10 It is estimated by historians that by 1950 a total of approximately 12 million Germans had fled or been expelled from East-Central Europe, and that between 500,000 and 2 million died as a result of the expulsions, although this latter number might be exaggerated as a result of political propaganda, lack of empirical data, and vague definitions; see: R. Overmans, Personelle Verluste der deutschen Bevölkerung durch Flucht und Vertreibung, "Dzieje Najnowsze" 1994, Vol. 26(2); T. Kamusella, The Expulsion of the Population Categorized as "Germans" from the Post-1945 Poland, in: S. Prauser, A. Rees (eds.), The Expulsion of the German Communities from Eastern Europe at the end of the Second World War, European University Institute, San Domenico 2004, pp. 21-33. It must however be noted that the Polish Minister of Foreign Affairs, Władysław Bartoszewski, addressed the question of expulsions during his speech in Bundestag on 28 April 1995 with the words "We bemoan the individual fate and the suffering of innocent Germans who were affected by the consequences of the war and lost their homes". Although it was not an apology in the strict sense, it demonstrated empathy for the innocent victims of this tragic armed conflict. See the text of the speech in Polish: http:// www.berlin.msz.gov.pl/resource/9df0ac0e-b38f-4b6c-b084-591fc2302a97:JCR [accessed: 20.03.2019]. 


\section{VARIA}

Karolina Wierczyńska

amounts of money to Polish citizens who were victims of war crimes committed by the Third Reich (for imprisonment in German concentration and forced labour camps or other Nazi persecutions). ${ }^{11}$ In turn, German citizens did not receive any financial compensation from Poland for the loss of their property due to their expulsion from Poland. As to the claims formulated by the former owners of properties which after the Potsdam and Yalta agreements became a part of Polish territory, the issue is complex. The European Court for Human Rights (ECtHR) assessed the complaints of German citizens as inadmissible ${ }^{12}$ and rejected them. It held that the purported individual acts of violence, expulsion, dispossession, and seizure or confiscation were instantaneous acts which occurred before the ratification of Protocol No. 1 by Poland and which did not produce any continuing effects that could have consequences for its jurisdiction ratione temporis. The Court added that the European Convention for the Protection of Human Rights and Fundamental Freedoms $(E C H R)^{13}$ imposes no specific obligation on States to provide redress for wrongs or damage caused prior to the ratification of the ECHR by that State. In this context any claims formulated before the ECtHR will be rejected as inadmissible and this is the current situation of eventual claims in the context of international law. The only available legal solution is for German owners and their heirs to settle any such claims directly with the Polish State in the course of judicial civil proceedings before Polish courts.

German claims as to the return of cultural goods are mainly focused on two objects which were sent East to avoid the bombardment of Berlin, namely the Prussian State Library in Berlin ${ }^{14}$ (called Berlinka in Polish) and Hermann Goering's collections of aircraft (called officially "German Collections of Aircraft"; in German: Deutsche Luftfahrtsammlung). ${ }^{15}$ Both objects are now part of Polish collections. Berlinka exists as the part of the collection of the Library of Jagiellonian University, which partly provides free access, while Goering's collection is a part of a permanent exposition of the Polish Aviation Museum in Kraków.

Apart from the above collections, certain claims could be formulated with regard to: on the one hand the cultural assets left behind by expelled Germans during the post-war resettlements which resulted from the shifting of borders;

\footnotetext{
11 For an extensive analysis of this issue, see J. Barcz, J. Kranz, op. cit., pp. 137-193.

12 See Preussische Treuhand GmbH \& Co. Kg A.A. v. Poland, Application No. 47550/06, Decision of inadmissibility of 7 October 2008, paras. 55-62, and Gerhard Stumpe v. Poland, Application No. 7913/07, Decision of inadmissibility of 9 December 2008.

134 November 1950, 213 UNTS 221.

14 See Stiftung Preußischer Kulturbesitz, op. cit.

15 See, for example: H. Steinle, Die Berliner Luftfahrtsammlung, "Bauwelt" 2010, Vol. 44, https://www.bauwelt.de/themen/Die-Berliner-Luftfahrtsammlung-Berlin-Aviatisches-Museum-Johannisthal-Luftfahrtmuseum-Krakau-2095938.html [accessed: 20.03.2019].
} 
and on the other lost cultural assets looted from Germany at the end of war. ${ }^{16}$ As to the latter, any cultural object which is recognized as looted from Germany shall be returned in the way of restitution, including restitutions from Poland.

The situation was also complicated afterwards because of the political situation, namely the post-war division of Germany into two different political blocs. Poland did not maintain diplomatic relations with the Federal Republic of Germany (known as West Germany or the FRG), but only with the German Democratic Republic (East Germany or GDR) - and Poland was (rather against its will) associated with the communist bloc. As a consequence the question of the allocation of cultural property remained - with the exception of some sporadic, individual restitutions and symbolic gestures ${ }^{17}$ - tacit and open until the end of the Cold War and the collapse of communism in Europe. The late 1980s and early 1990s gave rise to seismic changes not only in the relations with respect to cultural heritage. After the diplomatic breakthrough with Poland in 1989, the re-unification of Germany in 1990, the Polish-German border treaty and the Treaty on the final settlement with respect to Germany, which constituted a permanent determination of united Germany's area and borders (including the Polish-German border), the settlements contained in the Potsdam Treaty were de facto deconstructed and revised, which allowed for a new beginning. ${ }^{18}$

16 See, for example: German Lost Art Foundation, Lost Art Database, http://www.lostart.de/Webs/EN/ LostArt/Index.html [accessed: 2.01.2018].

17 See, for example: A. Jakubowski, Dziedzictwo kulturowe w stosunkach polsko-niemieckich w świetle norm i doktryny prawa międzynarodowego [Cultural heritage in Polish-German relations in the light of norms and doctrine of international law], in: W. Czapliński, B. Łukańko (eds.), Problemy prawne w stosunkach polsko-niemieckich u progu XXI wieku [Legal problems in Polish-German relations at the beginning of 21st century], Scholar, Warszawa 2009, p. 258; B. Jurkowicz, Kwestia zwrotu dóbr kultury w stosunkach polsko-niemieckich [Question of the return of cultural goods in Polish-German relations], "Biuletyn Opinie FAE" 2013, Vol. 17, p. 6.

18 It must be noted however that the history of Polish-German relations still pervades the political life, and especially that several animosities remain and are used in the current political disputes, as for example the claims of Preußischen Treuhand or the CDU-CSU 2009 initiative to condemn the post-war expulsions of Germans, including from Poland. See: M. Day, Angela Merkel's Party Backs "Homeland" for Germans Expelled by Poland, "The Telegraph", 29 June 2009, http://www.telegraph.co.uk/news/worldnews/europe/poland/5687591/Angela-Merkels-party-backs-homeland-for-Germans-expelled-by-Poland.html [accessed: 27.12.2017]; or initiatives in the politics of the party presently governing Poland (Prawo i Sprawiedliwość [Law and Justice], PiS) aimed at obtaining reparations from Germany, even though it seems that Poland effectively renounced reparations in 1953. See: N. Durman, Reparacje wojenne od Niemiec to dopiero poczatek. Poset PiS idzie o krok dalej [War reparations from Germany are only the beginning. A Law and Justice MP goes a step further], 13 September 2017, https://wiadomosci.wp.pl/reparacje-wojenne-od-niemiec-to-dopieropoczatek-posel-pis-idzie-o-krok-dalej-6165654854215297a [accessed: 27.12.2017]; or this party's distrust towards Germany on the political level, being at the moment the continuance of its policy commenced in 2005, S. Raabe, Polska - sasiad, partner, przyjaciel na wschodzie. Zmienne losy stosunków polsko-niemieckich po 1989 roku [Poland - a neighbour, partner, and friend in the east. The changeable fate of Polish-German relations after 1989], "Raporty Fundacji Konrada Adenauera" 2010, Vol. 17, p. 10. 


\section{VARIA}

Karolina Wierczyńska

\section{International multilateral instruments}

When WWII commenced, the protection of cultural heritage was already a recognized principle of international law ${ }^{19}$ and the restitution of cultural property looted during armed conflict was also a recognized international custom..$^{20}$ Both Germany and Poland were State Parties of the Hague Convention (IV) respecting the Laws and Customs of War on Land ("the 1907 Hague Convention (IV)"), accepted in 1907 and ratified by Germany in 1909 and by Poland in 1925. Just after WWII some efforts were made to resolve the restitution issues comprehensively and a programme for the restitution of looted cultural objects was discussed - but only partly finalized - during the first years after the war. But because of the lack of a peace treaty between Poland and Germany the question of reparations for the loss of cultural heritage was not definitively regulated. ${ }^{21}$

However, both German States - the Federal Republic of Germany and German Democratic Republic - as well as Poland, having in mind the experience of previous wars and unimaginable destruction of cultural objects in those countries, tended to undertake initiatives to protect and preserve the goods which remained on the international level. Before the collapse of the Soviet bloc they undertook several initiatives aimed at the protection of cultural heritage. They joined, inter alia, several international agreements focused on the protection of cultural property, namely: the Convention for the Protection of Cultural Property in the Event of Armed Conflict, with Regulations for the Execution of the Convention ("the 1954 Hague Convention"); ${ }^{22}$ the Protocol for the Protection of Cultural Property in the Event of Armed Conflict ("the First Protocol"); ${ }^{23}$ the European Cultural Convention; ${ }^{24}$ the Convention on the Means of Prohibiting and Preventing the Illicit Import, Export and Transfer of Ownership of Cultural Property ("the 1970 UNESCO Con-

\footnotetext{
19 This is visible, for example, in the Convention (IV) respecting the Laws and Customs of War on Land, 18 October 1907, https://ihl-databases.icrc.org/ihl/INTRO/195 and Articles 27 and 56 of its annex. This Convention bound Poland and Germany already before WWII.
}

20 W. Kowalski, Repatriacja dóbr kultury [Repatriation of cultural goods], in: G. Czubek, P. Kosiewski (eds.), Dobra kultury i problemy własności. Doświadczenia Europy Środkowej po 1989 roku [Cultural goods and the problem of ownership. The experience of Central Europe after 1989], Fundacja im. Stefana Batorego, Warszawa 2005, pp. 189-190; A. Jakubowski, Dziedzictwo..., p. 255.

21 For a broad overview of the question of post-war regulations, see: S.E. Nahlik, Grabież dziet sztuki: rodowód zbrodni międzynarodowej [Plunder of works of art: genesis of international crime], Ossolineum, Wrocław 1958; J. Pruszyński, Dziedzictwo kultury Polski: jego straty i ochrona prawna [Polish culture heritage: its losses and legal protection], Vol. II, Zakamycze, Kraków 2001; W. Kowalski, Likwidacja skutków II wojny światowej w dziedzinie kultury [Liquidation of the effects of the Second World War in the field of culture], Instytut Kultury, Warszawa 1994.

2214 May 1954, 249 UNTS 240; Poland joined in 1956, GDR in 1974, and FRG in 1967.

2314 May 1954, 249 UNTS 358; Poland joined in 1956, GDR in 1974, and FRG in 1967.

2419 December 1954, ETS 18. Although the Convention was adopted in 1954 and was open for non-State Parties of the Council of Europe, Poland ratified it only in 1989, while the FRG did so in 1955. 
vention); ${ }^{25}$ and the Convention Concerning the Protection of the World Cultural and Natural Heritage ("the 1972 UNESCO Convention"). ${ }^{26}$

Those treaties already demanded the protection of cultural heritage, both during times of peace and during an armed conflict. However, it must be noted that although States in some instances undertook obligations sanctioning acts which were a common practice only a decade earlier, they were not all State Parties to the given conventions, and they ratified certain conventions at different times, so it cannot be assumed that there existed any unitary model of protection of the cultural heritage between the German States and Poland. They decided to develop an international protection of cultural property because of the fact that cultural property suffered a massive amount of damage during WWII, and the techniques of warfare were developing, constantly increasing the danger for cultural heritage; but during the Cold War their national attitudes were different. Additionally, the agreements adopted after the war could not be applied retroactively. They were aimed at providing future protection, not resolving problems surrounding past claims.

A minimum standard of protection was defined in the 1954 Hague Convention, which was ratified by both German States and Poland. Article 4, Paragraphs 1 and 3 - entitled "Respect for cultural property" - declare that

High Contracting Parties undertake to respect cultural property situated within their own territory as well as within the territory of other High Contracting Parties by refraining from any use of the property and its immediate surroundings or of the appliances in use for its protection for purposes which are likely to expose it to destruction or damage in the event of armed conflict; and by refraining from any act of hostility, directed against such property;

and additionally declare that: "High Contracting Parties further undertake to prohibit, prevent and, if necessary, put a stop to any form of theft, pillage or misappropriation of, and any acts of vandalism directed against, cultural property. They shall refrain from requisitioning movable cultural property situated in the territory of another High Contracting Party".

The First Protocol to the above Convention concerned the obligations of a State Party which occupied a certain territory concerning the protection of cultural property. It provides, inter alia, that the State is obliged to prevent the exportation of cultural property from the occupied territory and the State shall return any seized property. Accordingly, the State Party shall "return, at the close of hostilities, to the competent authorities of the territory previously occupied, cultural property which is in its territory [...]. Such property shall never be retained as war reparations".

2514 November 1970, 823 UNTS 231; Poland joined in 1974, Germany in 2007.

2616 November 1972, 1037 UNTS 151; FRG and Poland joined in 1976 and GDR in 1988. 
Currently, Poland and Germany are State Parties to the 1970 UNESCO Convention. ${ }^{27}$ Both States are also members of Council of Europe, and State Parties of its conventions, and both States also have their national committees in the International Council of Museums (ICOM), which fights against the illicit trafficking in cultural goods. ${ }^{28}$ Additionally both States are members of the European Union (EU), which means that they are equally obliged to implement European law, including Directive 2014/60/EU of the European Parliament and of the Council of 15 May 2014 on the return of cultural objects unlawfully removed from the territory of a Member State ("Directive"). ${ }^{29}$ In transposing the Directive, Germany implemented the Act on the protection of cultural property, ${ }^{30}$ while Poland passed the Law on the restitution of the national cultural goods. ${ }^{31}$ In practice, implementation of the provisions of the Directive means that the international legal order of restitution, and the national order of restitution can both be replaced by the order of European law. The Directive also introduces a term of three years for return proceedings, ${ }^{32}$ and according to its Article 14 the Directive shall apply only to cultural objects unlawfully removed from the territory of a Member State on or after 1 January 1993, but States are free to make other arrangements. It could be postulated that if the cooperation within the framework of this regulation turns out to be successful, Poland and Germany could think about extending its provisions to determine the question of objects removed from their territories before 1993.

All these considerations allow us to assume that future cooperation and the protection of cultural heritage is secured, while the remaining unresolved issues centre around the problematic past and lack of a legal mechanism which would allow for an effective resolution of the problem of "lost" cultural property.

27 The legal situation of both States in the context of ratified or accepted international agreements concerning question of culture can be compared using the website of UNESCO. For Germany, see: https:// en.unesco.org/countries/germany/conventions; and for Poland: https://en.unesco.org/countries/poland/ conventions [accessed: 22.03.2019].

28 International Council of Museums, Fighting Illicit Traffic, http://icom.museum/programmes/fighting-illicit-traffic [accessed: 11.01.2018].

29 OJ L 159, 28.05.2014, p. 1.

30 Gesetz zum Schutz von Kulturgut, 31 July 2016, Federal Law Gazette Part I, p. 1914, https://www. gesetze-im-internet.de/englisch_kgsg/englisch_kgsg.html [accessed: 22.03.2019]. For more on German law implementing the Directive, see: R. Peters, The Protection of Cultural Property: Recent Developments in Germany in the Context of New EU Law, "Santander Art and Culture Law Review" 2016, Vol. 2(2), pp. 85-102.

31 Ustawa z dnia 25 maja 2017 r. o restytucji narodowych dóbr kultury, Dz.U. 2017, item 1086. For a critical assessment of the Polish project, see: P. Stec, The Lady or the Tiger? Legal Pitfalls of Implementing the Return of Cultural Goods Directive, "Santander Art and Culture Law Review" 2016, Vol. 2(2), pp. 135-148. 


\section{Bilateral agreements}

It was undoubtedly the end of the Cold War that opened this new chapter in the Polish-German relations and the question of "lost" cultural heritage finally began to be taken into consideration at the same time as attention was paid to the protection of remaining goods. The situation began to stabilize after the Treaty on the Final Settlement with Respect to Germany (also known as the "Two Plus Four Agreement", German: Zwei-plus-Vier-Vertrag). ${ }^{33}$ This treaty was negotiated in 1990 between the Federal Republic of Germany, the German Democratic Republic, and the Four Powers, i.e. the treaty States which occupied Germany after the end of WWII in Europe. As a result, France, the Soviet Union, the United Kingdom, and the United States renounced all rights they held in Germany, and declared that "The united Germany shall comprise the territory of the Federal Republic of Germany, the German Democratic Republic and the whole of Berlin. Its external borders shall be the borders of the Federal Republic of Germany and the German Democratic Republic and shall be definitive from the date on which the present Treaty comes into force". This resulted in the two German States being reunited and becoming a fully sovereign State the following year.

This situation naturally influenced the Polish-German relationship, and as a result both States finally signed in November 1990 a treaty which settled the question of the Polish-German border ${ }^{34}$ - an issue which in terms of international law had been pending since the end of WWII. This was followed by a treaty on good neighbourly relations and friendly cooperation, signed in June 1991 ("the 1991 Treaty"). ${ }^{35}$ Signing the 1991 Treaty was a milestone in the mutual relations between these two States, which until then had been rather strained. In the preamble of the 1991 Treaty the States declared their intention to close the painful chapters of their past. Such a conciliatory approach was employed with regard to the issue of cultural cooperation, including cultural heritage as broadly conceived. The fundamental principle expressed in the 1991 Treaty was international cooperation. The provisions of the 1991 Treaty refer to, inter alia, the situation of the German minority in Poland and the freedoms and laws of persons having German citizenship but Polish origin (Articles 21, 21); cultural cooperation (Article 23); cultural institutes (Article 24); access to language and culture (Article 25); and the preservation and nurture of the European cultural heritage (Article 28).

\footnotetext{
3312 September 1990, 1696 UNTS 115.

34 Treaty between the Federal Republic of Germany and the Republic of Poland on the Confirmation of the Frontier between Them, 14 November 1990, https://www.un.org/Depts/los/LEGISLATIONANDTREATIES/PDFFILES/TREATIES/DEU-POL1990CF.PDF [accessed: 20.03.2019].

35 Treaty between the Federal Republic of Germany and Poland on Good Neighbourly Relations and Friendly Cooperation, 17 June 1991, 1708 UNTS 463. Original text of the Treaty in German and Polish: http://25de.pl/dokumenty/traktat-o-dobrym-sasiedztwie-i-przyjaznej-wspo,25.html [accessed: 20.03.2019].
} 


\section{VARIA}

Karolina Wierczyńska

According to the provisions of the 1991 Treaty, the cultural cooperation between the States was to be intensified. An existing mixed commission was supposed to evaluate the cooperation at least once a year and make arrangements with respect to further actions. The States also decided to implement and make full use of the arrangements referring to the establishment of cultural institutes.

Article 28 obliged the States to

take special care of the places and cultural assets in their respective territories that bear witness to historical events and cultural and scientific achievements of the other side, and [...] provide free and unhindered access to them, or endeavour to see that such access is provided, where the state does not have authority to guarantee it. Such places and cultural assets shall be placed under the protection of the laws of the respective Contracting Parties. The Contracting Parties shall take joint initiatives in this area, in a spirit of understanding and reconciliation. ${ }^{36}$

The Article further stated that both States would, in "the same spirit", seek "to solve problems relating to cultural property and archives, beginning with individual cases". As noted by Andrzej Jakubowski,

[t]he last provision was particularly important for the pending controversies over the lists of cultural items requested by both sides. Since the solution of such disputes was greatly conditioned by the contradictory interpretations of the international effects of the 1945 Potsdam Agreement, Poland and Germany decided that their settlement would be negotiated on a case-by-case basis, in the spirit of reconciliation. ${ }^{37}$

Such a regulation demanded an individual approach to the question of restitutions and the employment of bilateral negotiations. It did not propose any concrete solutions referring to the restitution of Polish cultural objects looted by the Nazis or the return of German objects which remained in Poland after the shifting of the borders consequent to Potsdam and Yalta agreements.

One of the most challenging topics during the German-Polish negotiations concerning the 1991 Treaty was the question of compensation for Nazi crimes. In the end, both sides agreed for a payment of 500 million marks to the Polish victims of the Nazi regime. However, the amount, distributed by the Foundation for Polish-German Reconciliation, did not constitute reparations in the formal legal sense; rather they were "humanitarian aid" or "voluntary financial payments" than reparations in the moral, symbolic, and legal dimension.

For a few first years it seemed that such a solution would fulfil the expectations of both States, as in accordance with the 1991 Treaty a bilateral commission was established to enable bilateral negotiations. However, the ensuing years showed

36 A. Jakubowski, State Succession in Cultural Property, Oxford University Press, Oxford 2015, p. 278.

37 Ibidem. 
that restitution based on case-by-case solutions would not - if treated as the primary way to implement the 1991 Treaty - succeed in fulfilling the expectations and would never replace an overall solution. Instead, it was only an ad hoc and rather chaotic, as well as woefully slow, response to the settlement of the problem of the restitution of thousands of cultural objects.

The 1991 Treaty was supplemented by the Agreement between the Government of the Federal Republic of Germany and the Government of the Republic of Poland Concerning Cultural Cooperation concluded in 1997 ("the 1997 Agreement"). ${ }^{38}$ The question of lost/not returned cultural heritage was not included in this treaty, and Article 15 of the 1997 Agreement stated in a rudimentary fashion that problems of cultural heritage - including the problems connected with cultural property and archives - are regulated by Article 28 of the 1991 Treaty. The 1997 Agreement was, however, a very important basis to commence cooperation in all the other areas and was perceived for years as a "kind of phenomenon in Polish-German relations because of its richness, scope, variety and intensity". ${ }^{39}$

\section{The 1991 Treaty in practice, the Washington Principles,} and other challenges concerning the restitution of cultural heritage and cultural initiatives

The 1991 Treaty constituted the basis for several implemented solutions and political gestures concerning the return of cultural objects. Among others, one can mention the return of the numismatic collection and gold ornaments stolen from museums in Warsaw and Posen (1992); ${ }^{40}$ the exchange of archaeological objects by the National Museum in Stettin and the Pomeranian State Museum in Greiswald (2004); 41 the further negotiations concerning the return of Berlinka to Germany (pending since 1990, with no significant results owing to the difference in legal stances taken by both States, which will be developed below); ${ }^{42}$ and the submission of 114 restitutional applications (claims) to Germany by Poland, together with full documentation and the indication of their places of storage (1995). ${ }^{43}$

\footnotetext{
3814 July 1997, 2060 UNTS 221.

39 M. Wagińska-Marzec, Cultural Cooperation in the Light of the Provisions of the Treaties and Agreements (1990-2010), "Przegląd Zachodni" 2011, Vol. 2, p. 173.

40 A. Jakubowski, Dziedzictwo..., p. 269.

41 W. Kowalski, Restytucja..., p. 13.

42 For a broad overview, see: B. Jurkowicz, The Collection of the Prussian State Library. Polish, German, or European Cultural Heritage?, in: K. Ziemer (ed.), Memory and Politics of Cultural Heritage in Poland and Germany, Uniwersytet Kardynała Stefana Wyszyńskiego, Warszawa 2015, p. 123.

43 D. Matelski, Zabiegi Trzeciej Rzeczypospolitej o restytucję z Niemiec dziedzictwa kultury polskiej utraconego do 1945 roku [Efforts of the Third Polish Republic for the restitution from Germany of Polish cultural heritage lost until 1945], "Rocznik Bibliologiczno-Prasoznawczy" 2012, Vol. 4/15(1), p. 121; Matelski points out that Polish representative Tadeusz Polak, who presented claims for restitution, left with no answer.
} 
However, the initiatives taken were not always satisfactory to the States. Additionally, no international agreement was adopted, nor have any arrangements been made regarding the return of Berlinka to Germany or its status, as a result of which Germany stopped the negotiations. Talks undertaken in 1997 were again stopped for the same reason. A few gestures were made in the following years, as for example in 1999 when Jerzy Buzek, Prime Minister of Polish government, donated to German Chancellor Gerhard Schroeder the set of documents from Polish archives concerning the territory of the former GFR. Following this gesture, the talks concerning "Berlinka" were resumed. At the same time a few other symbolic gestures were made, such as another donation in 2000 by Prime Minister Buzek to Chancellor Schroeder, from the resources of the Prussian State Library, of Luther's Bible from 1522; or the restitution of the Etruscan mirror from Hamburg to the Palace in Gołuchów in 2002.

Nonetheless, while the practice in this matter must be assessed as unsatisfactory it encouraged States to undertake other efforts to achieve the restitution of cultural property looted during WWII under discriminatory Nazi policies. In the following years, many States and cultural institutions moved to settle these issues in other ways. Beside the bilateral relations between Poland and Germany, the question of the restitution of cultural heritage looted and displaced in 1939-1945 was raised in various international forums and led to the adoption and implementation of a set of different non-binding principles and declarations. In particular, the various States and different fora developed a consensus on non-binding principles to assist in resolving issues relating to Nazi confiscated art in the form of the Washington Principles, adopted during a conference in $1998,{ }^{44}$ which refer to the cultural objects confiscated by the Nazis and not subsequently returned to the original owners or their heirs (i.e. did not concern State to State restitution). The principles formulated in Washington relate to alternative dispute resolution mechanisms for resolving ownership issues and achieving just and fair solutions if the owners of confiscated art or their heirs cannot be identified. According to these principles, cultural objects should be identified and such information shall be publicized with the aim of creating a central registry containing such information. The main prob-

\footnotetext{
44 Washington Conference Principles on Nazi-Confiscated Art, 3 December 1998, https://www.state. gov/p/eur/rt/hlcst/270431.htm [accessed: 13.04.2019]. This was followed with many similar initiatives aimed at the restitution of cultural assets looted during the Holocaust era to the original owners or their heirs, for example: Resolution 1205 of the Council of Europe "Looted Jewish cultural property", 5 November 1999, https://www.lootedart.com/MG7Q8X93594 [accessed: 13.04.2019]; Vilnius Forum Declaration, 5 October 2000, http://www.lootedart.com/MFV7EE39608 [accessed: 13.04.2019]; Terezin Declaration, 30 June 2009, https://www.lootedartcommission.com/NPNMG484641 [accessed: 13.04.2019]. See the summary written by Maria Wagińska-Marzec on the occasion of the 20th anniversary of adoption of the Washington Principles: Niemcy i restytucja dóbr kultury wświetle „Deklaracji Waszyngtońskiej” [Germany and the restitution of cultural goods in the light of the Washington Principles], "Biuletyn Instytutu Zachodniego" 2018, Vol. 374, https://www.iz.poznan.pl/plik,pobierz,2904,8525e4907d3415f96f5aab400adc70 a2/Biuletyn\%20nr\%20374.pdf [accessed: 23.03.2019].
} 
lem however is verification of the provenance of objects exhibited in many collections in museums all around the world, as only some of them agreed to do so, based on an implied promise that suspect works would be returned to rightful owners if the evidence so dictates. This process is, however, time-consuming and slow, although in accordance with the Washington Principles some museums have made lists of suspect objects as being the victims of war theft. The compilation of these data allows for the verification of the origin of works and the restitution of war losses. On this basis several objects were returned from the Museum in Berlin to the National Museum in Gdańsk, including, inter alia, paintings of Anton Möller (Allegory of the Five Senses), Daniel Schultz (Fox and Grapes), and the wooden figure of a standing boy by Ernesto de Fiori. ${ }^{45}$ Additionally, some other cultural goods were restituted from Germany, such as the painting of Francesco Guardi Palace Stairs to the National Museum in Warsaw (2014); ${ }^{46}$ parchments stolen from Plock, e.g. the Plock Pontifical (2015); and lastly the Red-Figured Lekythos, ${ }^{47}$ which was the first archaeological artefact returned in 2018.

These examples of negotiations leading to successful restitutions are, however, still only pieces of a very broad problem, as there are thousands of lost objects of Polish cultural heritage still abroad, and thousands of restitution applications are not yet settled. The scale of this problem is illustrated by the words of Jarosław Sellin, Deputy Minister of Culture and National Heritage, who observed that: "Poland is recovering a work of art lost during World War II every five days on average". ${ }^{48}$ This actually means that the restitution of missing objects one by one, on an individual basis, ${ }^{49}$ will probably never be finally completed and will demand massive personal and financial resources to keep it going.

Thus the discussions are still ongoing, and from time to time they become intense due to some discoveries, like for example the Gurlitt collection in 2010 an immense collection of art works gathered by Hildebrand Gurlitt, a Nazi art dealer. ${ }^{50}$ Such incidents place the topic of Nazi art plunder in plain view of

\footnotetext{
45 For a broad overview, see: H. Kowalska, L. Łopuski, M. Mielnik, Z Berlina do Gdańska [From Berlin to Gdańsk], "Cenne, Bezcenne, Utracone" 2013, Vol. 1(74)-4(77), p. 28.

46 See, for example: Division for Looted Art, Guardi Painting Looted in Second World War Returns to Poland, 28 February 2014, http://dzielautracone.gov.pl/en/news/74-guardi-painting-looted-in-second-world-warreturns-to-poland [accessed: 11.01.2018].

47 See: Wydział Restytucji Dóbr Kultury, Pierwszy odzyskany zabytek archeologiczny [The first restituted archaeological object], http://dzielautracone.gov.pl/aktualnosci/184-pierwszy-odzyskany-zabytek-archeologiczny [accessed: 20.03.2019].

48 Poland Recovering Art Lost in WWII Every Five Days: Official, 1 December 2017, http://www.lootedart. com/news.php?r=SRT3TS401471 [accessed: 22.03.2019].

49 This is broadly described in D. Matelski, op. cit., p. 137.

50 J. Mansky, Why It's So Hard to Find the Original Owners of Nazi-Looted Art, 31 May 2017, https://www. smithsonianmag.com/arts-culture/why-its-so-hard-find-real-owners-nazi-looted-art-180963513/ [accessed: 11.01.2018].
} 


\section{VARIA}

Karolina Wierczyńska

international public opinion anew. The discovery led Polish historians to start a discussion on the restitution of Polish cultural heritage objects, based on the likelihood that the Gurlitt collection includes looted Polish paintings (as it was already evident that parts of the whole collection were not legally obtained, but proven to be looted). ${ }^{51}$

Although the Polish Ministry of Foreign Affairs filed an application to the prosecutor's office in Augsburg for a complete list of the artworks discovered in the apartment of collector Cornelius Gurlitt (son of Hildebrand) in Munich a while ago, and a team of experts from several countries, including Poland, was established, the work on just the identification of the objects in the collection is going very slow, as the provenance and the condition of many objects are questionable. It must however be noted that thanks to this affair Polish claims have received a better response in Germany. So far one painting coming from a Polish collection has been recognized in Gurlitt's collection - Horace Vernet's painting titled Mort du prince Józef Poniatowski à la bataille de Leipzig (The Death of Prince Józef Poniatowski in the Battle of Leipzig). ${ }^{52}$

\section{Today's Perspective - Recent Decades}

Today the situation with regard to Polish-German relations in the area of cultural heritage is much different than it was 20 years ago. While the fall of the iron curtain and Poland's membership in the Council of Europe were the first steps toward normalizing relations, it was Poland's accession drive to join the EU and its membership thereof that today exerts the most influence on the relationship between the two States, as the EU States have developed common mechanisms and institutions to protect cultural heritage and to develop peaceful relations.

\section{The role of institutions}

As regards the institutional support in the area of cultural heritage the main responsible public institution in Germany is the German Lost Art Foundation (Deutsches Zentrum Kulturgutverluste), founded in $2015 .{ }^{53}$ It focuses on cultural assets confiscated by the National Socialists through persecution, particularly from former Jewish owners (so-called "Nazi confiscated art"). The Foundation acts according

51 See the press information: Five of Gurlitt's Art Works Proved to be "Looted", "The Local", 14 January 2016, https://www.thelocal.ch/20160114/only-five-of-gurlitts-art-works-proved-to-be-looted [accessed: 11.01.2018]; Gurlitt's collection is catalogued here: http://www.lostart.de/Webs/EN/Datenbank/Gurlitt/ KunstfundMuenchen.html [accessed: 20.03.2019].

52 See: http://www.lostart.de/EN/Fund/478440 [accessed: 11.03.2019].

53 The Foundation itself was founded in 2015 , but formerly was acting on the basis of the Coordination Office (Koordinierungs-stelle der Länder für die Rückführung von Kulturgütern), see: https://www.kulturgutverluste.de/Webs/EN/Foundation/Chronology/Index.html [accessed: 20.03.2019]. 
to the Washington Principles and is responsible for investigating the war-related removal or relocation of cultural property ("looted art") as well as the loss of cultural assets under Soviet occupation and in the GDR. The Foundation supports provenance research with research grants and provides information on reports of lost and found cultural assets via its open-access Lost Art Database (lostart.de). The database has currently documented almost 200,000 lost cultural objects. ${ }^{54}$ The Foundation is managed and represented by its executive board, but its highest decision-making body is the foundation board, which is chaired by the Minister of State for Culture and Media, Prof. Monika Grütters..$^{55}$

In Poland, the question of restitution and compensation is continuing under the auspices of the Unit for Restitution of Cultural Goods, acting within the structure of Polish Ministry of Foreign Affairs. The Unit (in the persons of Wojciech Kowalski and Monika Kuhnke) closely cooperates with the Ministry of Culture and National Heritage and its departments within the National Heritage Department, which supervises the Division for Looted Art. The Division for Looted Art is the operator of the electronic database of Wartime Losses, the only Polish national register of cultural property lost as a result of WWII, which gathers data on the objects looted as a result of warfare. The data present in the database forms a useful basis for searches of wartime losses, and documents the restitution activities undertaken by the Division for Looted Art.

\section{Identified Problems: Main Controversies}

At the moment the main controversy in Polish-German relations related to cultural heritage looted, dispersed, and/or displaced during WWII refers to 1) the insufficiently effective (and in some cases non-effective) restitution of Polish cultural objects from Germany; and 2) the problem of Berlinka. It seems that the restitution of looted art to Poland will be continued, as more and more initiatives are undertaken via both governmental and non-governmental actions, including preparing universal international databases registering the looted art, exchanges between museums, as well as restitutional gestures between States. It also must be noted that the question of restitution of stolen objects has periodically depended on the effects of the negotiations with respect to Berlinka, although there is a clear difference between the legal status of Berlinka and the art confiscated by Nazis.

\footnotetext{
54 See: Kulturgutverluste, Fact Sheet, 24 August 2018, https://www.kulturgutverluste.de/Content/08 Downloads/EN/Fact-sheet.pdf;jsessionid=AA43943B729E6F85CC172A5A17F3ECFD.m7?_blob=publicationFile\&v=17 [accessed: 20.03 .2019 ].

55 Apart from the documentation of the lost art, the Foundation is also responsible for overseeing the "Gurlitt Provenance Research" project described above. The Foundation also provides editorial support in the maintenance of the online portal concerning the protection of cultural property in Europe (http:// www.kulturgutschutz-deutschland.de/DE/Home/home_node.html).
} 
The art stolen or confiscated from Poland during WWII should be returned by way of its restitution. It was Germany which started the war of aggression, and Germany bears the responsibility for this fact, as well as the responsibility for the return of stolen cultural property or the payment of compensation if the requested objects were destroyed. This is regulated by international law, which as mentioned above is binding on both States. Restitution was already recognized as part of customary law before the war, and confirmed as a written principle by the First Protocol to the 1954 Hague Convention accepted by States after the war. Similarly, the obligation to pay compensation by a State violating humanitarian law, perceived currently as customary law, was already expressed in 1907 Hague Convention (IV), which was ratified by Germany and Poland already before WWII.

The Prussian State Library, which constitutes a symbol of German culture, was evacuated during the bombardment of Berlin to the eastern part of what was then the Third Reich, which however after the end of war and the Potsdam Agreement became Polish territory. Poland never looted the Prussian State Library from anybody or anywhere - it was found on its territory after the war ended. From that moment on it has been officially treated as "abandoned property" and Poland deems itself to be the owner of the collection. Thus returning the library will eventually be connected with its repatriation or return ${ }^{56}$ (if the States succeed in negotiations), as it cannot be the subject of restitution (which refers to property illegally obtained).

Germany's arguments concerning the place of storage or legal status of the Prussian State Library are not uniform. On the one hand, some German lawyers have tended to refer to the Berlinka as a category of "looted art", or the "last prisoner of war", underlying that its elements are legally and morally part of its national patrimony and should be returned. Tono Eitel, who was the chief German negotiator for the return of cultural objects, recalled the 1907 Hague Convention (IV) and Articles 27 and 56 of its regulations, stating that the convention "forbids confiscating art works". ${ }^{57}$ In his opinion, on the basis of this Convention the library collection should be returned to Germany. However, he did not exclude the possibility that the collection might be governed by a Polish-German institution, such as a foundation, which would take care of the deposited collection. On the other hand, certain voices appeared presenting a more conciliatory approach as to the place

56 W. Kowalski, Rodzaje roszczeń o odzyskanie utraconych dóbr kultury [Types of claims for the recovery of lost cultural goods], in: G. Czubek, P. Kosiewski (eds.), Przemieszczone dobra kultury. Przypadek Europy Zachodniej i problemy państw Europy Środkowej i Wschodniej w XX wieku [Displaced cultural goods. The case of Western Europe and the problems of the countries of Central and Eastern Europe in the 20th century], Fundacja im. Stefana Batorego, Warszawa 2004, p. 42.

57 See the interview: https://polishpress.wordpress.com/2007/08/06/poland-will-not-return-pricelessart-works-to-germany/ [accessed: 15.01.2018]. 
of storage of the Prussian State Library, ${ }^{58}$ underlying the fact that although it was created in Germany and is mostly connected with German territory, it also contains a number of objects being a part of the European cultural heritage, which could be exhibited elsewhere. ${ }^{59}$

Poland has never accepted the German position referring to the library as looted art. Poland's main arguments are based on the facts that Poland did not commence a war of aggression; was not an occupying power; and did not steal or loot the Prussian State Library. The regulations of the 1907 Hague Convention (IV) thus do not refer to it, as it was not an occupying power. Poland has continually argued that it legally acquired title to the collection as a result of the Potsdam Agreement, and that the collection may be treated as restitution-in-kind as a consequence of the policy of the Nazis, which destroyed Polish cultural heritage to such an extent and in such an amount as to constitute grounds for compensation. ${ }^{60}$

This position however has been criticized by the German doctrine, ${ }^{61}$ which argues that such claims are unjustified as Poland could not have obtained ownership of the collection, and additionally that the doctrine of restitution-in-kind was not accepted by States in the area of cultural heritage after the war. It sometimes adds that the decision on the form of reparation cannot be a unilateral decision on the part of one State. ${ }^{62}$

The situation of the Prussian library can only be perceived as complicated and complex. Firstly, the positions of both States are at the moment non-negotiable; secondly, the positions are based on different legal grounds and assumptions; and thirdly the majority of regulations implementing fundamental international principles as to the standard procedures concerning cultural heritage during an armed conflict - which could be useful to solve the issue - were accepted after the war and cannot be applied to facts that took place before their adoption. To the contrary, the international regulations ratified by States before the war (i.e. the aforementioned 1907 Hague Convention (IV)) are rather rudimentary and do not allow for making any general statements as to the legal status and the place of storage of the Prussian library. Nor is there any international custom that could be taken into account. It seems that Berlinka is a hostage of Polish expectations concerning its obtainment of restitution/compensation from Germany; and that Germany does not want to discuss the question of restitution until Berlinka is returned. To resolve this "Catch 22" situation further negotiations are needed, and not necessarily

58 See D. Matelski, op. cit., p. 134.

59 B. Jurkowicz, The Collection..., p. 124.

60 A. Jakubowski, State Succession..., p. 278.

61 S. Turner, Das internationale Kulturgüterrecht und die Zerstreuung des deutchen Kulturbesitzes nach dem Zweiten Weltkrieg, in: W. Fiedler (ed.), Internationaler Kulturgüterschutz und deutsche Frage, Gebr. Mann Verlag, Berlin 1991, p. 180.

62 A. Jakubowski, State Succession..., p. 279. 


\section{VARIA}

Karolina Wierczyńska

conducted by or engaging governmental institutions. It is also possible that Germany, by raising the issue of Berlinka, wishes to avoid the question of restitution and the lack of any systemic solution between States to resolve the outstanding issues concerning restitutional claims. Thus both States have adopted a comfortable solution which does not demand any legal effort, especially given that individual restitutions on a case-by-case basis are still pending, thus neither can be accused of inaction or inactivity.

\section{The charm of alternatives}

Regardless of the status of official negotiations, alternative solutions as to the future of Berlinka have been formulated by other fora - for example the Copernicus Group, a forum of independent experts representing both Polish and German scholars (lawyers, historians), in their second report in 2000.63 They proposed that the Prussian Cultural Heritage Foundation should take Poland as a partner (which would require a change in the statute of the Foundation) and that the collection would then be deposited in a new department of the Foundation - the Library of Jagiellonian University. Such a solution does not require a change of the place of storage of the collection. But the Copernicus Group also proposed other solutions; for example the creation of a European Cultural Heritage Foundation, or a Central-Europe Cultural Heritage Foundation, with the Prussian Cultural Heritage Foundation representing Germany in the newly established institution. Poland could be invited to provide such a foundation with its cultural assets of European significance. Consequently, the countries which conduct bilateral negotiations over the return of cultural property (like Poland and Germany) would be able to make decisions as equal partners among the Foundation authorities regarding the preservation of European cultural heritage.

Additionally the report of the Copernicus Group also referred to the cultural goods looted from Poland. According to the experts, Germany should submit a list of the works of art that were illegally confiscated and transported from Poland during WWII. Those cultural objects which, according to Poland, are omitted from the list will be investigated by an independent institution and the results of the research will be published. The objects mentioned on the list shall be restituted immediately. However, notwithstanding the above-mentioned proposals for a solution, the fact remains that after almost two decades the situation with respect to Berlinka - i.e. its legal status and place of storage - remains unchanged (the same is true with respect to Goering's aircraft).

63 Working papers and reports of the Copernicus Group can be obtained here: http://www.deutsches-polen-institut.de/politik/kopernikus-gruppe/\#arbeitspapiere, both in German and Polish. 
Apart from this dispute itself, several initiatives have taken place concerning the preservation and digitization of the collection, as well as scientific research into it. Among others it must be mentioned that thanks to a grant allotted by the Commissary for Culture and Media of the German Federal Government and the cooperation of the Library of Jagiellonian University, the Staatsbibliothek zu Berlin (under the auspices of the Prussian Cultural Heritage Foundation) has been able to take the first steps towards a virtual reconstruction of the old East Asia Collection of the Prussian State Library. In addition, Deutschen Forschungsgemeinschaft has supported the preparation of a collection of French manuscripts from $2006^{64}$ the "Autographa Collection" - one of the most valuable collections of the former Prussian State Library. This collection has been developed after several years of intensive work and is now included in a comprehensive two-part catalogue (book and $\mathrm{CD}-\mathrm{ROM}$ ). The new catalogue replaces an incomplete and difficult-to-read manuscript/list from the first half of the 20th century. For the first time it describes the largely unknown, historically significant autographs from the former Prussian State Library, which combine letters and other handwritten writings of important personalities from five centuries under the name "Autographa Collection". It encompasses other extremely valuable testimonies as well, such as, inter alia, $443 \mathrm{mu}$ sic autographs by Bach, Mozart, and Beethoven. ${ }^{65}$ As part of this collaboration the Foundation maintains professional contacts with the Polish cultural institutions which hold the displaced cultural assets.

The Prussian collection is also researched by specialists, for example the research team of Piotr Tylus - Fibula - which decided to start a research project on the romance manuscripts in the Prussian collection. The actions of the Fibula group included identification of manuscripts, their origins, original ownership, and also their partial digitization. ${ }^{66}$ In this way collection of Berlinka is living its own life apart from the governmental disputes, and must be perceived as a truly European cultural heritage.

\section{Cultural Cooperation in Other Areas}

Fortunately, in other sectors of cultural cooperation the unresolved problems from the past have not hindered the Polish-German relations concerning the promotion and protection of cultural heritage and mutual cooperation. Accord-

\footnotetext{
64 Staatsbibliothek zu Berlin, Katalog der in Krakau verwahrten Autographen-Sammlung der ehemaligen Preußischen Staatsbibliothek erschienen: Ergebnis einer deutsch-polnischen Zusammenarbeit, 12 November 2007, http://staatsbibliothek-berlin.de/en/aktuelles/presse-news/detail/article/2007-12-11-22/ [accessed: 15.01 .2018$]$.

65 Ibidem.

66 The website of the Group: http://www.rekopisy-romanskie.filg.uj.edu.pl/fibula/en; more about the group can be found in the newsletters published online presenting the results of the research: http://www. rekopisy-romanskie.filg.uj.edu.pl/fibula/pl/newsletter [accessed: 11.01.2018].
} 
ing to a survey concluded for the Institute of Public Affairs, Körber-Stiftung, and Konrad-Adenauer-Stiftung - titled Germans and Poles. A Divided Past, a Common Future? - as many as $70 \%$ of Germans and $60 \%$ of Poles prefer to focus current mutual relations on the present and future not on the past. At the same time there are also signs warranting a certain caution: While $50 \%$ of Poles think that "the sacrifices that the Polish people have made throughout history have not been sufficiently recognised by the international public", only $17 \%$ of Germans are of the same opinion. And while $64 \%$ of Poles hold the view that the relations with their German neighbours are good, less than a half of Germans (31\%) share this view. ${ }^{67}$

This short description of the survey demonstrates that although war reparations still play a role in mutual relations, apart from the official narratives both nations are looking toward the future and share the view that current mutual relations should rather be focused on the present and future than the past. This seems especially important and symbolic now in light of the fact that since 2015 the Polish-German official relationship has been going through a significant regress due to the current Polish objections as to the gas pipeline NordStream2; Poland's repeated claims concerning war reparations; and the amendments to the Polish law on the Institute of National Remembrance, ${ }^{68}$ which caused an international uproar.

Both States, at different levels of cooperation, perceive culture as an instrument serving international dialogue and contributing to soothing political and social tensions. Moreover, the applied solutions between Poland and Germany seem very effective and comprehensive in terms of developing mutual relations. Both States have launched a number of joint cultural projects or cultural initiatives, some through a special bilateral commission established on the basis of the 1997 Agreement. Many cultural initiatives are also undertaken by both sides not only on the inter-state level, but also as initiatives of non-governmental organizations, societies, foundations, or artists. The issues of Berlinka and art looted during the WWII are problems with tendencies to be raised anew depending on political narratives, while the cultural cooperation in other areas is almost free from prejudice and political influences. ${ }^{69}$

\footnotetext{
67 Körber-Stiftung, Institute of Public Affairs, Konrad-Adenauer-Stiftung, Germans and Poles. A Divided Past, a Common Future? Results of the Polish-German Barometer 2018, https://www.isp.org.pl/uploads/drive/ oldfiles/A/barometrang.pdf [accessed: 31.01.2019].

68 See Angela Merkel and Mateusz Morawiecki Seek to Repair German-Polish Relations, "DW", 16 February 2018, https://www.dw.com/en/angela-merkel-and-mateusz-morawiecki-seek-to-repair-german-polishrelations/a-42609999 [accessed: 5.02.2019].

69 Annual statistics underline the fact that Polish-German relations are estimated by $2 / 3$ of respondents as either very good or good; see: A. Łada, Barometr Polska - Niemcy 2017: Polskie społeczeństwo o niemieckiej polityce i wzajemnych relacjach [Barometer Poland - Germany 2017: Polish society on German policy and mutual relations], Instytut Spraw Publicznych, Warszawa 2017, p. 14, http://www.kas.de/wf/doc/kas_ 48898-1522-8-30.pdf?170516224041 [accessed: 14.01.2017].
} 


\section{Polish culture and German culture - an institutional perspective $\mathrm{e}^{70}$}

There are several dozen institutions which promote German and Polish culture in Poland and Germany. At least a few should be mentioned: the Polish Institute in Berlin (with its branch in Leipzig) and the Polish Institute in Düsseldorf, Instytut Adama Mickiewicza, Polski Instytut Sztuki Filmowej, Instytut Książki, Instytut Teatralny, Narodowy Instytut Fryderyka Chopina, and the Centre of Historical Research of the Polish Academy of Sciences in Berlin.

Polish culture is promoted by Deutsch-Polnische Gesellschaften, ${ }^{71}$ which, inter alia, publishes the magazine titled: "Dialog", aimed at the development of mutual relations and combating stereotypes; Die Deutsch-Polnische Stiftung Kulturpflege und Denkmalschutz, ${ }^{72}$ which intensifies cooperation in the area of the conservation of monuments and is engaged in the renovation of historical objects in Poland (recent initiatives include the renovation of the Palace in Steinort; renovation of Mikwe der Synagoge zum Weißen Storch in Breslau; and restoration and renovation of the baroque altar of the Cistercian Monastery Church in Paradies [Paradyż]).

As regards the promotion of German culture in Poland, among many initiatives two should be specifically mentioned: the initiatives of the Goethe-Institut; ${ }^{73}$ and the institute of German culture and the German Head-Office for Academic Exchange (Deutscher Akademischer Austausch Dienst), ${ }^{74}$ which develops mostly educational projects between Poland and Germany.

Additionally the actions of two German foundations must be mentioned the Robert Bosch Stiftung and Konrad-Adenauer-Stiftung..$^{75}$ The first, apart from the immense contribution in the context of Karl-Dedecius-Preis and the Copernicus Group, also develops other projects. For example, between 1991-2001 it helped to digitize and register in catalogues 40,000 publications recognized as Polish and German cultural heritage, and over 5 million old prints from the 16th-18th centuries and periodicals from the 19th century, and moreover it supported programmes of partnership between towns. ${ }^{76}$ Konrad-Adenauer-Stiftung supports political cooperation, and its civic education programmes aim at promoting freedom and liberty, peace, and justice. Some other institutions could be mentioned as focused

\footnotetext{
70 This contribution lists only some examples of initiatives, as it is impossible to provide an exhaustive list in this respect. As noted by M. Wagińska-Marzec, Cultural Cooperation..., p. 182, there are several dozens of Polish-German associations promoting Polish and German culture registered in Germany. Hence this sub-section provides only a representative list.

71 Website: https://www.dpg-bundesverband.de/start.html [accessed: 20.03.2019].

72 Website: http://deutsch-polnische-stiftung.de [accessed: 20.03.2019].

73 Website: https://www.goethe.de/ins/pl/pl/index.html [accessed: 20.03.2019].

74 Website: https://www.daad.pl/en/ [accessed: 20.03.2019].

75 Website: http://www.kas.de/wf/en/71.3628/ [accessed: 20.03.2019].

76 Website: http://www.bosch-stiftung.de/content/language1/html/53764.asp?lang=pl [accessed: 20.03.2019].
} 
specifically on Polish-German relations, such as the Herder Institute for Historical Research in East-Central Europe, ${ }^{77}$ or the Federal Institute for Culture and History of Germans in Eastern Europe. ${ }^{78}$

It is impossible to recount all of the cultural events, educational cultural programmes, or common projects which have taken place in Germany and in Poland within the cooperation between both countries since 1990 until the present moment. By the way of example one may mention the Year of Chopin, "Chopin 2010" in Germany; the 20th anniversary of the signing of the 1991 Treaty (and later the 25th anniversary of signing of this Treaty), celebrated pompously with numerous events and publications $;{ }^{79}$ and in 2011 an exhibition of art took place in Berlin titled Side by Side. Poland - Germany. 1000 Years of Art and History. ${ }^{80}$

As a result of inter-state and inter-regional collaboration, certain initiatives were undertaken to preserve and protect objects of cultural heritage. Among others, inscription on the World Heritage List (WHL) must be mentioned, as in 2005 a jointly-administered cultural site was inscribed on the list: Muskauer Park/Park Mużakowski - a park located on the border of Poland and Germany. In 2006 Germany supported the inscription on the WHL of another site - the Centennial Hall in Wrocław. This clearly demonstrates that certain objects of culture are perceived as the common cultural heritage of both States, and that both States wish to preserve and protect it as a heritage for future generations.

Within another project - "Zapomniane dziedzictwo" (Vergessenes Erbe) ${ }^{81}$ under the auspices of the House for Polish-German Co-operation, ${ }^{82}$ the German consulate in Opole, and public authorities from the region, an internet website was created to present the objects which used to be the heritage of Silesia. This site contains archival and current photographs of places that were once the showcase of the region, and today for various reasons are abandoned, destroyed, not renovated, and somehow forgotten.

Last year (2018) was proclaimed the European Year of Cultural Heritage, and along with this unique event another project was commenced concerning collaboration between the Czech Republic, Poland, and Germany. The common goal of this

77 One can mention for example projects connected with historical aerial photography of the cities of Wrocław/Breslau and Gdańsk/Danzig - important places in German-Polish history; similar initiative is connected with Upper Silesia, see here: https://www.herder-institut.de/en/research-projects/current-projects/upper-silesia-from-the-air.html [accessed: 20.03.2019].

78 See: https://www.bkge.de/EN/ [accessed: 20.03.2019].

79 The website of the anniversary: http://25pl-de.eu/jubilee-year.html [accessed: 20.03.2019].

80 Website of the event: http://culture.pl/en/event/side-by-side-poland-germany-1000-years-of-artand-history [accessed: 20.03.2019].

81 The website of the project "Zapomniane dziedzictwo": http://zapomnianedziedzictwo.pl/de/ [accessed: 15.01.2018]. 
German-Polish-Czech cooperation is to make a contribution to the visual history of the transcultural industrial and cultural landscape of Upper Silesia. ${ }^{83}$ The project is based on the inventory of the historical oblique and vertical aerial photographs created in the Scientific Collections of the Herder Institute in the period 1920-1945, as well as current oblique aerial images of the Berlin photographer Thomas Voßbeck, a renowned specialist in industrial photography. The project is a kind of a continuance of previous initiatives, as the idea arose from book and exhibition projects that had already been undertaken and completed by the Herder Institute. These projects were focused on historical aerial photographs of the cities of Wrocław/Breslau and Gdańsk/Danzig. Both cities share a Polish and German history: while now located on the territory of Poland, they were also part of Germany, thus constituting a natural heritage of a common past.

Lastly, some attention must be paid to the scientific projects that can be applied for in the Polish-German scientific space; for example those funded by the National Science Centre and Deutsche Forschungsgemeinschaft research projects and called Beethoven projects (Beethoven classic and Beethoven life). ${ }^{84}$ These research projects refer to the humanities, social and art sciences, and selected disciplines of exact and technical sciences, and are implemented by Polish-German teams. So far a few editions of Beethoven have been organized and several dozen teams representing both States carry out these mutual projects.

\section{Conclusions}

The key question posed in this article concerned the problem of the Polish-German relationship with respect to cultural heritage from 1990-2019. It was pointed out that the main dividing lines in mutual relations refer to the unresolved problems from the period of WWII. The main controversy in cultural cooperation between Poland and Germany relates to war losses and the collections of the Prussian State Library (evacuated at the end of the WWII by the German administration to the territories which in 1945 passed under Polish rule). In the last few years the public, official Polish-German relations are again seen as being in regress, especially at the level of governmental cooperation, but it seems that this does not disturb the process of reconciliation between the States in other areas (such as culture), where overall the cooperation is developing smoothly regardless of political narratives.

Most definitely mutual cooperation must extend far beyond war losses and war reparations, regardless of the line of official state policy. As the Barometer survey showed - people want to look toward the future not the past. The peoples of both countries want to cooperate closely in the area of art, preservation of art, and

83 Herder-Institute, Oberschlesien aus der Luft, https://www.herder-institut.de/forschung-projekte/ laufende-projekte/oberschlesien-aus-der-luft.html [accessed: 15.01.2018].

84 See: https://ncn.gov.pl/finansowanie-nauki/konkursy/typy [accessed: 20.03.2019]. 


\section{VARIA}

Karolina Wierczyńska

education. More than half of Germans (59\%) and Poles (53\%) support the idea that their children should study history from a common Polish-German history textbook, ${ }^{85}$ which shows that the respective societies are aware of the delicate nature of and special need for good Polish-German relations. Regardless of official state positions, the German and Polish societies are ready for a next step and real reconciliation, without political narratives and biased approaches.

\section{References}

Agreement between the Government of the Federal Republic of Germany and the Government of the Republic of Poland Concerning Cultural Cooperation, 14 July 1997, 2060 UNTS 221.

Alford K.D., Hermann Göring and the Nazi Art Collection: The Looting of Europe's Art Treasures and Their Dispersal After World War II, McFarland \& Company, Jefferson, NC 2012.

Angela Merkel and Mateusz Morawiecki Seek to Repair German-Polish Relations, "DW", 16 February 2018, https://www.dw.com/en/angela-merkel-and-mateusz-morawiecki-seekto-repair-german-polish-relations/a-42609999 [accessed: 5.02.2019].

Barcz J., Kranz J., Reparacje od Niemiec po drugiej wojnie światowej w świetle prawa międzynarodowego. Aspekty prawa i praktyki [Reparations from Germany after the Second World War in the light of international law: practical and legal aspects], Dom Wydawniczy Elipsa, Warszawa 2019.

Chechi A., The Settlement of International Cultural Heritage Disputes, Oxford University Press, New York 2014.

Cieślińska-Lobkowicz N., Węzeł Poczdamski. O powojennych rewindykacjach dóbr kultury związanych ze zmiana polskich granic [Potsdam's knot. About post-war vindications of cultural goods connected with the change of borders], in: G. Czubek, P. Kosiewski (eds.), Dobra kultury i problemy własności. Doświadczenia Europy Środkowej po 1989 roku [Cultural goods and the problem of ownership. Experience of Central Europe after 1989], Fundacja im. Stefana Batorego, Warszawa 2005.

Convention (IV) respecting the Laws and Customs of War on Land, 18 October 1907, https://ihl-databases.icrc.org/ihl/INTRO/195.

Convention Concerning the Protection of the World Cultural and Natural Heritage, 16 November 1972, 1037 UNTS 151.

Convention for the Protection of Cultural Property in the Event of Armed Conflict, 14 May 1954, 249 UNTS 240.

Convention for the Protection of Human Rights and Fundamental Freedoms, 4 November 1950, 213 UNTS 221.

Convention on the Means of Prohibiting and Preventing the Illicit Import, Export and Transfer of Ownership of Cultural Property, 14 November 1970, 823 UNTS 231.

Council of Europe European Cultural Convention, 19 December 1954, ETS 18.

Day M., Angela Merkel's Party Backs "Homeland" for Germans Expelled by Poland, "The Telegraph", 29 June 2009, http://www.telegraph.co.uk/news/worldnews/europe/poland/

85 See: Körber-Stiftung, Institute of Public Affairs, Konrad-Adenauer-Stiftung, op. cit. 
5687591/Angela-Merkels-party-backs-homeland-for-Germans-expelled-by-Poland. html [accessed: 27.12 .2017$]$.

Directive 2014/60/EU of the European Parliament and of the Council of 15 May 2014 on the return of cultural objects unlawfully removed from the territory of a Member State and amending Regulation (EU) No 1024/2012 (Recast), OJ L 159, 28.05.2014.

Division for Looted Art, Guardi Painting Looted in Second World War Returns to Poland, 28 February 2014, http://dzielautracone.gov.pl/en/news/74-guardi-painting-looted-in-second-world-war-returns-to-poland [accessed: 11.01.2018].

Durman N., Reparacje wojenne od Niemiec to dopiero początek. Poset PiS idzie o krok dalej [War reparations from Germany are only the beginning. A Law and Justice MP goes a step further], 13 September 2017, https://wiadomosci.wp.pl/reparacje-wojenne-od-niemiec-to-dopiero-poczatek-posel-pis-idzie-o-krok-dalej-6165654854215297a [accessed: 27.12.2017].

Estreicher K., Cultural Losses of Poland: Index of Polish Cultural Losses During the German Occupation, 1939-1944, London 1944.

European Court of Human Rights, Gerhard Stumpe v. Poland, Application No. 7913/07, Decision of inadmissibility of 9 December 2008.

European Court of Human Rights, Preussische Treuhand GmbH \& Co. Kg A.A. v. Poland, Application No. 47550/06, Decision of inadmissibility of 7 October 2008.

Five of Gurlitt's Art Works Proved to be "Looted", "The Local", 14 January 2016, https://www. thelocal.ch/20160114/only-five-of-gurlitts-art-works-proved-to-be-looted [accessed: 11.01.2018].

Gesetz zum Schutz von Kulturgut [Act on the protection of cultural property], 31 July 2016, Federal Law Gazette Part I, p. 1914, https://www.gesetze-im-internet.de/englisch_ kgsg/englisch_kgsg.html [accessed: 22.03.2019].

Jakubowski A., Dziedzictwo kulturowe w stosunkach polsko-niemieckich w świetle norm i doktryny prawa międzynarodowego [Cultural heritage in Polish-German relations in the light of norms and doctrine of international law], in: W. Czapliński, B. Łukańko (eds.), Problemy prawne w stosunkach polsko-niemieckich u progu XXI wieku [Legal problems in Polish-German relations at the beginning of 21st century], Scholar, Warszawa 2009.

Jakubowski A., State Succession in Cultural Property, Oxford University Press, Oxford 2015.

Jurkowicz B., Kwestia zwrotu dóbr kultury w stosunkach polsko-niemieckich [Question of the return of cultural goods in Polish-German relations], "Biuletyn Opinie FAE" 2013, Vol. 17.

Jurkowicz B., The Collection of the Prussian State Library. Polish, German, or European Cultural Heritage?, in: K. Ziemer (ed.), Memory and Politics of Cultural Heritage in Poland and Germany, Uniwersytet Kardynała Stefana Wyszyńskiego, Warszawa 2015.

Kamusella T., The Expulsion of the Population Categorized as "Germans" from the Post-1945 Poland, in: S. Prauser, A. Rees (eds.), The Expulsion of the German Communities from Eastern Europe at the end of the Second World War, European University Institute, San Domenico 2004.

Körber-Stiftung, Institute of Public Affairs, Konrad-Adenauer-Stiftung, Germans and Poles. A Divided Past, a Common Future? Results of the Polish-German Barometer 2018, https:// www.isp.org.pl/uploads/drive/oldfiles/A/barometrang.pdf [accessed: 31.01.2019]. 


\section{VARIA}

Karolina Wierczyńska

Kowalska H., Łopuski L., Mielnik M., Z Berlina do Gdańska [From Berlin to Gdańsk], "Cenne, Bezcenne, Utracone" 2013, Vol. 1(74)-4(77).

Kowalski W., An Appraisal of the Losses to Polish Cultural Heritage Resulting from German Aggression During the Second World War, in: W. Góralski (ed.), Polish-German Relations and the Effects of the Second World War, Polish Institute of International Affairs, Warsaw 2006.

Kowalski W., Likwidacja skutków II wojny światowej w dziedzinie kultury [Liquidation of the effects of the Second World War in the field of culture], Instytut Kultury, Warszawa 1994.

Kowalski W., Poland. Part I: Historical Overview, "Spoils of War" 1995, Vol. 1, https://www. lootedart.com/web_images/pdf2016/Spoils\%20of\%20War\%201.pdf [accessed: 20.03.2019].

Kowalski W., Repatriacja dóbr kultury [Repatriation of cultural goods], in: G. Czubek, P. Kosiewski (eds.), Dobra kultury i problemy własności. Doświadczenia Europy Środkowej po 1989 roku [Cultural goods and the problem of ownership. The experience of Central Europe after 1989], Fundacja im. Stefana Batorego, Warszawa 2005.

Kowalski W., Restytucja dóbr kultury utraconych przez Polskę w okresie II wojny światowej jako element polskiej polityki zagranicznej realizowanej przez Ministerstwo Spraw Zagranicznych RP w latach 1999-2009 [Restitution of cultural goods lost by Poland during World War II as an element of Polish foreign policy implemented by the Ministry of Foreign Affairs of the Republic of Poland in 1999-2009], in: W. Kowalski, M. Kuhnke (eds.), Looted and Recovered. Restitution by the Ministry of Foreign Affairs of Poland's Cultural Property Lost During World War II, Ministerstwo Spraw Zagranicznych, Warsaw 2011.

Kowalski W., Rodzaje roszczeń o odzyskanie utraconych dóbr kultury [Types of claims for the recovery of lost cultural goods], in: G. Czubek, P. Kosiewski (eds.), Przemieszczone dobra kultury. Przypadek Europy Zachodniej i problemy państw Europy Środkowej i Wschodniej $w X X$ wieku [Displaced cultural goods. The case of Western Europe and the problems of the countries of Central and Eastern Europe in the 20th century], Fundacja im. Stefana Batorego, Warszawa 2004.

Łada A., Barometr Polska - Niemcy 2017: Polskie społeczeństwo o niemieckiej polityce i wzajemnych relacjach [Barometer Poland - Germany 2017: Polish society on German policy and mutual relations], Instytut Spraw Publicznych, Warszawa 2017, http://www.kas. de/wf/doc/kas_48898-1522-8-30.pdf?170516224041 [accessed: 14.01.2017].

Mansky J., Why It's So Hard to Find the Original Owners of Nazi-Looted Art, 31 May 2017, https://www.smithsonianmag.com/arts-culture/why-its-so-hard-find-real-ownersnazi-looted-art-180963513/ [accessed: 11.01.2018].

Matelski D., Zabiegi Trzeciej Rzeczypospolitej o restytucję z Niemiec dziedzictwa kultury polskiej utraconego do 1945 roku [Efforts of the Third Polish Republic for the restitution from Germany of Polish cultural heritage lost until 1945], "Rocznik Bibliologiczno-Prasoznawczy" 2012, Vol. 4/15(1).

Nahlik S.E., Grabież dzieł sztuki: rodowód zbrodni międzynarodowej [Plunder of works of art: genesis of international crime], Ossolineum, Wrocław 1958.

Overmans R., Personelle Verluste der deutschen Bevölkerung durch Flucht und Vertreibung, "Dzieje Najnowsze" 1994, Vol. 26(2).

Peters R., The Protection of Cultural Property: Recent Developments in Germany in the Context of New EU Law, "Santander Art and Culture Law Review" 2016, Vol. 2(2). 
Poland Recovering Art Lost in WWII Every Five Days: Official, 1 December 2017, http://www. lootedart.com/news.php?r=SRT3TS401471 [accessed: 22.03.2019].

Protocol for the Protection of Cultural Property in the Event of Armed Conflict, 14 May 1954, 249 UNTS 358.

Pruszyński J., Dziedzictwo kultury Polski: jego straty i ochrona prawna [Polish culture heritage: its losses and legal protection], Vol. II, Zakamycze, Kraków 2001.

Raabe S., Polska - sąsiad, partner, przyjaciel na wschodzie. Zmienne losy stosunków polsko-niemieckich po 1989 roku [Poland - a neighbour, partner, and friend in the east. The changeable fate of Polish-German relations after 1989], "Raporty Fundacji Konrada Adenauera" 2010, Vol. 17.

Resolution 1205 of the Council of Europe "Looted Jewish cultural property", 5 November 1999, https://www.lootedart.com/MG7Q8X93594 [accessed: 13.04.2019].

Staatsbibliothek zu Berlin, Katalog der in Krakau verwahrten Autographen-Sammlung der ehemaligen Preußischen Staatsbibliothek erschienen: Ergebnis einer deutsch-polnischen Zusammenarbeit, 12 November 2007, http://staatsbibliothek-berlin.de/en/aktuelles/ presse-news/detail/article/2007-12-11-22/ [accessed: 15.01.2018].

Stec P., The Lady or the Tiger? Legal Pitfalls of Implementing the Return of Cultural Goods Directive, "Santander Art and Culture Law Review" 2016, Vol. 2(2).

Steinle H., Die Berliner Luftfahrtsammlung, "Bauwelt" 2010, Vol. 44, https://www.bauwelt. de/themen/Die-Berliner-Luftfahrtsammlung-Berlin-Aviatisches-Museum-Johannisthal-Luftfahrtmuseum-Krakau-2095938.html [accessed: 20.03.2019].

Stiftung Preußischer Kulturbesitz, Holdings Evacuated to Poland, https://www.preussischer-kulturbesitz.de/en/priorities/provenance-research-and-issues-of-ownership/ wartime-losses/holdings-evacuated-to-poland.html [accessed: 20.03.2019].

Terezin Declaration, 30 June 2009, https://www.lootedartcommission.com/NPNMG484 641 [accessed: 13.04.2019].

Treaty between the Federal Republic of Germany and Poland on Good Neighbourly Relations and Friendly Cooperation, 17 June 1991, 1708 UNTS 463.

Treaty between the Federal Republic of Germany and the Republic of Poland on the Confirmation of the Frontier between Them, 14 November 1990, https://www.un.org/ Depts/los/LEGISLATIONANDTREATIES/PDFFILES/TREATIES/DEU-POL1990CF. PDF [accessed: 20.03.2019].

Treaty on the Final Settlement with Respect to Germany, 12 September 1990, 1696 UNTS 115.

Turner S., Das internationale Kulturgüterrecht und die Zerstreuung des deutchen Kulturbesitzes nach dem Zweiten Weltkrieg, in: W. Fiedler (ed.), Internationaler Kulturgüterschutz und deutsche Frage, Gebr. Mann Verlag, Berlin 1991.

Ustawa z dnia 25 maja 2017 r. o restytucji narodowych dóbr kultury [Law on the restitution of the national cultural goods], Dz.U. 2017, item 1086.

Vilnius Forum Declaration, 5 October 2000, http://www.lootedart.com/MFV7EE39608 [accessed: 13.04.2019].

Wagińska-Marzec M., Cultural Cooperation in the Light of the Provisions of the Treaties and Agreements (1990-2010), "Przegląd Zachodni" 2011, Vol. 2.

Wagińska-Marzec M., Niemcy i restytucja dóbr kultury w świetle „Deklaracji Waszyngtońskiej” [Germany and the restitution of cultural goods in the light of the Washington Princi- 


\section{VARIA}

Karolina Wierczyńska

ples], "Biuletyn Instytutu Zachodniego" 2018, Vol. 374, https://www.iz.poznan.pl/ plik,pobierz,2904,8525e4907d3415f96f5aab400adc70a2/Biuletyn\%20nr\%20374. pdf [accessed: 23.03.2019].

Washington Conference Principles on Nazi-Confiscated Art, 3 December 1998, https:// www.state.gov/p/eur/rt/hlcst/270431.htm [accessed: 13.04.2019].

Wydział Restytucji Dóbr Kultury, Pierwszy odzyskany zabytek archeologiczny [The first restituted archaeological object], http://dzielautracone.gov.pl/aktualnosci/184-pierwszy-odzyskany-zabytek-archeologiczny [accessed: 20.03.2019].

Żółtowski M., Zbiory Biblioteki Pruskiej w Polsce. Studium przypadku [Collection of Prussian library in Poland. Case study], Wydawnictwo Uniwersytetu Warszawskiego, Warszawa 2012. 